\title{
Utilization of Soil Health Card by Farmers in Nutrient Management
}

\author{
B. Padmaja* and J.G. Angadi \\ Department of Agricultural Extension Education \\ University of Agricultural sciences, Dharwad-580 005, Karnataka, India \\ *Corresponding author
}

Keywords

Utilization, Soil health card, Macro nutrients, Micro nutrients, Yield

\section{Article Info}

Accepted:

12 November 2018

Available Online:

10 December 2018

\section{A B S T R A C T}

The research study was conducted in Mylavaram and Ibrahimpatnammandals of Krishna district of Andhra Pradesh to assess the utilization of soil health card recommendations by farmers in nutrient management in paddy, sugarcane, cotton, maize and black gram crops with the sample size of 150 soil health card holders. Utilization of macro nutrients as per recommendations was observed in paddy and black gram. Paired ' $t$ ' test revealed nonsignificant difference in utilization of macro nutrients between first and second year after the distribution of soil health card with respect to all crops. Significant difference in application of micro nutrients was found among paddy, sugarcane and cotton crops in successive years. Increase in mean yield of sugarcane from 403.14 quintals (before distribution of soil health card) to 412.57 quintals per acre was noticed after soil health card distribution. Significant difference in mean yield was also observed in sugarcane. In case of cotton, significant difference in mean yield was not noticed in the first year after utilization of soil health card while it was significant in second year.

\section{Introduction}

Soil health plays a vital role to ensure agricultural production in a sustainable manner. Soil health needs to be assessed at regular intervals so as to ensure that farmers apply the required nutrients while taking advantage of the nutrients already present in the soil. Farmers will be able to know how much nutrients are already available in the soil and how much will have to be provided additionally for a particular crop through soil testing. Soil testing programme started in India in the year 1955-56 with the setting up of 16 Soil Testing Laboratories (STLs) under
"Determination of Soil Fertility and Fertilizer Use" programme (Anonymous, 2012). The central and state governments took many steps to sustain soil health for maximizing crop production. However, no uniform norms were followed in the country for soil analysis and distribution of such information before the issue of Soil health cards. Further, these initiatives were sporadic and random and therefore did not cover all the farmers within a particular time cycle. In the view, central government had launched the soil health card scheme in February 2015. Under this scheme, soil health cards are given to farmers for their land holdings for every 3 years. Soil health 
card is a printed report and it provides information about 12 soil parameters. It also suggests corrective measures that a farmer should adopt to obtain a better yield. With this background, the present study was undertaken to assess the usage of soil health card recommendations by farmers in nutrient management.

\section{Materials and Methods}

The study was an Ex-post facto research carried out inKrishna district of Andhra Pradesh. Krishna district consists of 50 mandals and among them, Mylavaram and Ibrahimpatnammandals were purposively selected and from each mandal five villages were selected based on the criteria of maximum number of soil health cards distributed to the farmers under soil health card scheme. From each village 15 farmers were selected by using simple random sampling to form a sample of 150 .

Utilization of Soil health card by farmers was studied taking into consideration quantity of application of various plant nutrients and amendments over successive two years in comparison with recommendations as per soil health card for different crops. The primary data about application of plant nutrients by soil health card holders for 2016 and 2017 was collected by using the schedule developed for the study. Paired ' $t$ ' test for two sample means was used to compare the utilization of soil health card recommendations by farmers in nutrient management for the past two years.

$t=\frac{\overline{\mid \mathrm{d} \|}}{\mathrm{s} / \sqrt{n}}$

Where,

$|\overline{\mathrm{d}}|=$ Mean difference, $\mathrm{s}=$ Sample variance, $\mathrm{n}$ $=$ Sample size

\section{Results and Discussion}

\section{Utilization of macro nutrients by farmers}

The data in Table 1 depicted the utilization of macro nutrients by the farmers in kharif paddy, rabi paddy, black gram, sugarcane, cotton and maize crops in successive two years.

In case of nitrogen utilization, 52.66 per cent farmers in first year and 62.00 per cent in second year in kharif paddy, 62.50 per cent in first year and 65.28 per cent in second year in black gram, 38.10 per cent in first year and 45.71 per cent in second year in rabi paddy had applied recommended dosage of nitrogen. Over dose of nitrogen was applied by 45.71 per cent farmers in first year and 48.57 per cent in second year in sugarcane, 45.45 per cent in first year and 39.34 per cent in second year in cotton, 46.67 per cent per cent in first year and 39.34 per cent in second year in maize.

With respect to phosphorus utilization, 71.42 per cent farmers in first year and 74.26 per cent in second year in sugarcane, 63.63 per cent in first year and 51.51 per cent in second year in cotton, 53.33 per cent in first year and 50.00 per cent in second year in maize belonged to over utilization category.Whereas,50.00 per cent farmers in first year and 51.33 per cent in second year in kharif paddy, 50.48 per cent in first year and 62.86 per cent in second year in rabi paddy, 50.00 per cent in first year and 63.89 per cent in second year in black gram belonged to recommended utilization category.

Regarding potassium, 56.00 per cent farmers in first year and 65.33 per cent in second year in kharif paddy, 55.55 per cent in first year and 62.50 per cent in second year in black gram, 41.90 per cent in first year and 49.52 per cent in second year in rabi paddy had 
applied recommended dosage of potassium. Over dosage of potassium was applied by 54.54 per cent farmers in first year and 51.52 per cent in second year in cotton, 45.71 per cent in first year and 48.57 per cent in second year in sugarcane, 46.67 per cent in first year and 43.33 per cent in second year in maize.

As far as sulphur utilization, 50.47per cent farmers in first year and 55.24 per cent in second year in rabi paddy, 73.61 per cent in first year and 76.39 per cent in second year in black gram, 36.00 per cent in first year and 49.33 per cent in second year in kharif paddy belonged to recommended utilization category. Whereas, 54.54 per cent farmers in first year and 51.52 per cent in second year in cotton, 48.57 per cent in first year and 37.14 per cent in second year in sugarcane, 43.33 per cent in first year and 40.00 per cent in second year in maize belonged to over utilization category.

Paired ' $t$ ' test (Table 2) revealed no significant difference in utilization of macro nutrients between first and second year after the distribution of soil health card with respect to all crops.

\section{Utilization of micro nutrients by farmers}

Utilization of micro nutrients by the farmers in kharif paddy, rabi paddy, sugarcane, cotton and maize crops in successive two years is presented in Table 3.

Zinc deficiency was found among kharif paddy, sugarcane, rabi paddy, cotton and maize growing farms of 74.67 per cent, 68.57 per cent, 49.52 per cent, 33.33 per cent and 23.33 per cent farmers respectively. The recommended dosage of zinc was applied by 52.68 per cent farmers in first year and 70.53 per cent in second year in the fields of kharif paddy, 58.33 per cent in first year and 70.83 per cent in second year in sugarcane, 50.00 per cent in first year and 57.69 per cent in second year in rabi paddy, 63.63 per cent in first year and 72.73 per cent in second year in cotton. Under utilization of zinc was observed among 71.43 per cent farmers in first year and 57.14 per cent in second year with respect to maize.

Boron deficiency was observed in sugarcane, cotton, kharif paddy, rabi paddy and maize fields of 51.43 per cent, 42.42 per cent, 37.33 per cent, 24.86 per cent and 23.33 per cent farmers respectively. The recommended dosage of boron was applied by 66.67 per cent in first year and 83.33 per cent in second year in sugarcane, 57.14 per cent in first year and 71.43 per cent in second year in cotton, 64.28 per cent farmers in first year and 85.71 per cent in second year in kharif paddy, 61.54 per cent in first year and 84.62 per cent in second year in rabi paddy. Under utilization of boron was noticed among 80.00 per cent farmers in first year and 60.00 per cent in second year in case of maize.

Utilization of micro nutrients recommendations increased from first year to second year in crops where there is deficiency. Table 4 revealed that significant difference in zinc application was noticed at one per cent level in kharif paddy, at five per cent level in rabi paddy, sugarcane and cotton. Significant difference in boron application was observed in paddy, sugarcane and cotton at five per cent level.

\section{Impact of soil health card on yield}

Table 5 depicts the mean yield levels of crops before and after distribution of soil health card. Increase in mean yield of sugarcane from 403.14 quintals (before distribution of soil health card) to 412.57 quintals per acre was noticed after soil health card distribution. The difference in mean yield was significant at one per cent level. The findings are in line with Makadia et al., (2017). 
Int.J.Curr.Microbiol.App.Sci (2018) 7(12): 1583-1592

Table.1 Utilization of macro nutrients by farmers

\begin{tabular}{|c|c|c|c|c|c|c|c|c|c|}
\hline \multirow[t]{3}{*}{ Sl.No. } & \multirow[t]{3}{*}{ Crop } & \multirow{3}{*}{$\begin{array}{c}\text { Macro } \\
\text { nutrients }\end{array}$} & \multirow[t]{3}{*}{ Year } & \multicolumn{6}{|c|}{ Extent of Utilization } \\
\hline & & & & \multicolumn{2}{|c|}{ Under } & \multicolumn{2}{|c|}{ Recommended } & \multicolumn{2}{|c|}{ Over } \\
\hline & & & & $\mathbf{f}$ & $\%$ & $\mathbf{f}$ & $\%$ & $\mathbf{f}$ & $\%$ \\
\hline \multirow[t]{8}{*}{1.} & \multirow{8}{*}{$\begin{array}{l}\text { K-Paddy } \\
(n=150)\end{array}$} & \multirow[t]{2}{*}{$\mathrm{N}$} & I & 11 & 7.33 & 79 & 52.66 & 60 & 40.00 \\
\hline & & & II & 11 & 7.33 & 93 & 62.00 & 46 & 30.67 \\
\hline & & \multirow[t]{2}{*}{$\mathrm{P}$} & $\mathrm{I}$ & 15 & 10.00 & 75 & 50.00 & 60 & 40.00 \\
\hline & & & II & 15 & 10.00 & 77 & 51.33 & 58 & 38.67 \\
\hline & & \multirow[t]{2}{*}{$\mathrm{K}$} & $\mathrm{I}$ & 2 & 1.33 & 84 & 56.00 & 64 & 42.67 \\
\hline & & & II & 0 & 0.00 & 98 & 65.33 & 50 & 33.33 \\
\hline & & \multirow[t]{2}{*}{$\mathrm{S}$} & I & 48 & 32.00 & 54 & 36.00 & 48 & 32.00 \\
\hline & & & II & 30 & 20.00 & 74 & 49.33 & 46 & 30.67 \\
\hline \multirow[t]{8}{*}{2.} & \multirow{8}{*}{$\begin{array}{l}\text { R-Paddy } \\
(n=105)\end{array}$} & \multirow[t]{2}{*}{$\mathrm{N}$} & I & 32 & 30.48 & 40 & 38.10 & 33 & 31.42 \\
\hline & & & II & 25 & 23.81 & 48 & 45.71 & 32 & 30.48 \\
\hline & & \multirow[t]{2}{*}{$\mathrm{P}$} & I & 16 & 15.24 & 53 & 50.48 & 36 & 34.28 \\
\hline & & & II & 15 & 14.29 & 66 & 62.86 & 24 & 22.86 \\
\hline & & \multirow[t]{2}{*}{$\mathrm{K}$} & I & 22 & 20.95 & 44 & 41.90 & 39 & 37.14 \\
\hline & & & II & 16 & 15.24 & 52 & 49.52 & 37 & 35.24 \\
\hline & & \multirow[t]{2}{*}{$\mathrm{S}$} & I & 28 & 26.67 & 53 & 50.47 & 24 & 22.86 \\
\hline & & & II & 24 & 22.86 & 58 & 55.24 & 23 & 21.90 \\
\hline \multirow[t]{8}{*}{3.} & \multirow{8}{*}{$\begin{array}{l}\text { Black gram } \\
\quad(n=72)\end{array}$} & \multirow[t]{2}{*}{$\mathrm{N}$} & I & 14 & 19.44 & 45 & 62.50 & 13 & 18.05 \\
\hline & & & II & 13 & 18.06 & 47 & 65.28 & 12 & 16.67 \\
\hline & & \multirow[t]{2}{*}{$\mathrm{P}$} & I & 6 & 8.33 & 36 & 50.00 & 30 & 41.66 \\
\hline & & & II & 9 & 12.5 & 46 & 63.89 & 17 & 23.61 \\
\hline & & \multirow[t]{2}{*}{$\mathrm{K}$} & I & 0 & 0.00 & 40 & 55.55 & 32 & 44.44 \\
\hline & & & II & 0 & 0.00 & 45 & 62.50 & 27 & 37.50 \\
\hline & & \multirow[t]{2}{*}{$\mathrm{S}$} & I & 13 & 18.05 & 53 & 73.61 & 6 & 8.33 \\
\hline & & & II & 13 & 18.05 & 55 & 76.39 & 4 & 5.56 \\
\hline
\end{tabular}

Continued... 
Int.J.Curr.Microbiol.App.Sci (2018) 7(12): 1583-1592

\begin{tabular}{|c|c|c|c|c|c|c|c|c|c|}
\hline \multirow[t]{8}{*}{4.} & \multirow{8}{*}{$\begin{array}{c}\text { Sugarcane } \\
\quad(n=35)\end{array}$} & \multirow[t]{2}{*}{$\mathbf{N}$} & I & 4 & 11.43 & 15 & 42.86 & 16 & 45.71 \\
\hline & & & II & 2 & 5.71 & 16 & 45.71 & 17 & 48.57 \\
\hline & & \multirow[t]{2}{*}{$\mathrm{P}$} & I & 2 & 5.71 & 8 & 22.86 & 25 & 71.42 \\
\hline & & & II & 2 & 5.71 & 7 & 20.00 & 26 & 74.26 \\
\hline & & \multirow[t]{2}{*}{$\mathrm{K}$} & I & 4 & 11.43 & 15 & 42.86 & 16 & 45.71 \\
\hline & & & II & 2 & 5.71 & 16 & 45.71 & 17 & 48.57 \\
\hline & & \multirow[t]{2}{*}{$\mathrm{S}$} & I & 10 & 28.57 & 12 & 34.29 & 13 & 37.14 \\
\hline & & & II & 8 & 22.86 & 12 & 34.29 & 15 & 42.86 \\
\hline \multirow[t]{8}{*}{5.} & \multirow{8}{*}{$\begin{array}{l}\text { Cotton } \\
(n=33)\end{array}$} & \multirow[t]{2}{*}{$\mathrm{N}$} & I & 11 & 33.33 & 7 & 21.21 & 15 & 45.45 \\
\hline & & & II & 8 & 24.24 & 12 & 36.36 & 13 & 39.34 \\
\hline & & \multirow[t]{2}{*}{$\mathrm{P}$} & I & 8 & 24.24 & 4 & 12.12 & 21 & 63.63 \\
\hline & & & II & 5 & 15.15 & 11 & 33.33 & 17 & 51.51 \\
\hline & & \multirow[t]{2}{*}{$\mathrm{K}$} & I & 5 & 15.15 & 10 & 30.30 & 18 & 54.54 \\
\hline & & & II & 3 & 9.09 & 13 & 39.39 & 17 & 51.52 \\
\hline & & \multirow[t]{2}{*}{$\mathrm{S}$} & I & 5 & 15.15 & 10 & 30.30 & 18 & 54.54 \\
\hline & & & II & 4 & 12.12 & 12 & 36.36 & 17 & 51.52 \\
\hline \multirow[t]{8}{*}{6.} & \multirow{8}{*}{$\begin{array}{l}\text { Maize } \\
(n=30)\end{array}$} & \multirow[t]{2}{*}{$\mathrm{N}$} & I & 6 & 20.00 & 10 & 33.33 & 14 & 46.67 \\
\hline & & & II & 5 & 16.67 & 12 & 40.00 & 13 & 43.33 \\
\hline & & \multirow[t]{2}{*}{$\mathrm{P}$} & I & 3 & 10.00 & 11 & 36.67 & 16 & 53.33 \\
\hline & & & II & 2 & 6.67 & 13 & 43.33 & 15 & 50.00 \\
\hline & & \multirow[t]{2}{*}{$\mathrm{K}$} & I & 6 & 20.00 & 10 & 33.33 & 14 & 46.67 \\
\hline & & & II & 5 & 16.67 & 12 & 40.00 & 13 & 43.33 \\
\hline & & \multirow[t]{2}{*}{$\mathrm{S}$} & I & 7 & 23.33 & 10 & 33.33 & 13 & 43.33 \\
\hline & & & II & 3 & 10.00 & 15 & 50.00 & 12 & 40.00 \\
\hline
\end{tabular}


Table.2 Comparison of macro nutrient utilization between two successive years

\begin{tabular}{|c|c|c|c|c|c|}
\hline \multirow[t]{2}{*}{$\begin{array}{l}\text { Sl. } \\
\text { No. }\end{array}$} & \multirow[t]{2}{*}{ Crop } & \multirow[t]{2}{*}{$\begin{array}{c}\text { Macro } \\
\text { nutrients }\end{array}$} & \multicolumn{2}{|c|}{$\begin{array}{c}\text { Average quantity in } \\
\text { Kilograms }\end{array}$} & \multirow[t]{2}{*}{$\begin{array}{l}\text { Paired } t- \\
\text { value }\end{array}$} \\
\hline & & & $1^{\text {st }}$ year & $2^{\text {nd }}$ year & \\
\hline \multirow[t]{4}{*}{1.} & \multirow{4}{*}{$\begin{array}{l}\text { K-Paddy } \\
(\mathrm{n}=150)\end{array}$} & $\mathrm{N}$ & 58.71 & 55.51 & 2.39 \\
\hline & & $\mathrm{P}$ & 13.24 & 12.25 & 1.81 \\
\hline & & K & 22.59 & 22.22 & 0.43 \\
\hline & & $S$ & 6.18 & 5.43 & 1.89 \\
\hline \multirow{4}{*}{2.} & \multirow{4}{*}{$\begin{array}{l}\text { R-Paddy } \\
(\mathrm{n}=105)\end{array}$} & $\mathrm{N}$ & 43.69 & 42.89 & 0.56 \\
\hline & & $\mathrm{P}$ & 9.31 & 9.28 & 0.04 \\
\hline & & K & 17.99 & 16.92 & 1.39 \\
\hline & & $S$ & 6.56 & 6.11 & 0.82 \\
\hline \multirow[t]{4}{*}{3.} & \multirow{4}{*}{$\begin{array}{l}\text { Black gram } \\
\quad(\mathrm{n}=72)\end{array}$} & $\mathrm{N}$ & 10.06 & 9.27 & 1.37 \\
\hline & & $P$ & 2.92 & 2.61 & 1.45 \\
\hline & & K & 2.71 & 2.36 & 0.74 \\
\hline & & $S$ & 1.22 & 1.16 & 1.01 \\
\hline \multirow[t]{4}{*}{4.} & \multirow{4}{*}{$\begin{array}{l}\text { Sugarcane } \\
\qquad(\mathrm{n}=35)\end{array}$} & $\mathrm{N}$ & 23.52 & 23.79 & 0.10 \\
\hline & & $\mathrm{P}$ & 5.43 & 5.59 & 0.89 \\
\hline & & K & 9.96 & 10.11 & 0.23 \\
\hline & & $S$ & 3.41 & 3.95 & 1.19 \\
\hline \multirow[t]{4}{*}{5.} & \multirow{4}{*}{$\begin{array}{l}\text { Cotton } \\
(n=33)\end{array}$} & $\mathrm{N}$ & 14.35 & 14.16 & 0.10 \\
\hline & & $\mathrm{P}$ & 0.92 & 0.83 & 0.81 \\
\hline & & K & 7.43 & 7.23 & 0.44 \\
\hline & & $S$ & 1.26 & 1.12 & 1.01 \\
\hline \multirow[t]{4}{*}{6.} & \multirow{4}{*}{$\begin{array}{l}\text { Maize } \\
(n=30)\end{array}$} & $\mathrm{N}$ & 17.02 & 16.80 & 0.23 \\
\hline & & $\mathrm{P}$ & 2.60 & 2.52 & 0.34 \\
\hline & & K & 5.90 & 5.84 & 0.08 \\
\hline & & $S$ & 1.43 & 1.38 & 0.37 \\
\hline
\end{tabular}


Int.J.Curr.Microbiol.App.Sci (2018) 7(12): 1583-1592

Table.3 Utilization of micronutrients by farmers

\begin{tabular}{|c|c|c|c|c|c|c|c|c|c|}
\hline \multirow{3}{*}{$\begin{array}{l}\text { Sl. } \\
\text { No. }\end{array}$} & \multirow[t]{3}{*}{ Crop } & \multirow{3}{*}{$\begin{array}{c}\text { Micro } \\
\text { nutrients }\end{array}$} & \multirow[t]{3}{*}{ Year } & \multicolumn{6}{|c|}{ Extent of utilization } \\
\hline & & & & \multicolumn{2}{|c|}{ Under } & \multicolumn{2}{|c|}{ Recommended } & \multicolumn{2}{|c|}{ Over } \\
\hline & & & & f & $\%$ & $\mathbf{f}$ & $\%$ & $\mathbf{f}$ & $\%$ \\
\hline \multirow[t]{4}{*}{1.} & \multirow{4}{*}{$\begin{array}{c}\text { K-Paddy } \\
(n=150)\end{array}$} & \multirow[t]{2}{*}{ Zinc $(n=112)$} & I & 46 & 41.07 & 59 & 52.68 & 7 & 6.25 \\
\hline & & & II & 25 & 22.32 & 79 & 70.53 & 8 & 7.14 \\
\hline & & \multirow[t]{2}{*}{ Boron $(\mathrm{n}=56)$} & I & 20 & 35.71 & 36 & 64.28 & 0 & 0.00 \\
\hline & & & II & 8 & 14.29 & 48 & 85.71 & 0 & 0.00 \\
\hline \multirow[t]{4}{*}{2.} & \multirow{4}{*}{$\begin{array}{l}\text { R-Paddy } \\
(n=105)\end{array}$} & \multirow{2}{*}{ Zinc (n=52) } & I & 18 & 34.61 & 26 & 50.00 & 8 & 15.38 \\
\hline & & & II & 17 & 32.69 & 30 & 57.69 & 5 & 9.61 \\
\hline & & \multirow[t]{2}{*}{ Boron(n=26) } & I & 10 & 38.46 & 16 & 61.54 & 0 & 0.00 \\
\hline & & & II & 4 & 15.38 & 22 & 84.62 & 0 & 0.00 \\
\hline \multirow[t]{4}{*}{3.} & \multirow{4}{*}{$\begin{array}{l}\text { Sugarcane } \\
\quad(\mathrm{n}=35)\end{array}$} & \multirow[t]{2}{*}{ Zinc $(n=24)$} & I & 8 & 33.33 & 14 & 58.33 & 2 & 8.33 \\
\hline & & & II & 3 & 12.50 & 17 & 70.83 & 4 & 16.67 \\
\hline & & \multirow[t]{2}{*}{ Boron(n=18) } & I & 6 & 33.33 & 12 & 66.67 & 0 & 0.00 \\
\hline & & & II & 3 & 16.67 & 15 & 83.33 & 0 & 0.00 \\
\hline \multirow[t]{4}{*}{4.} & \multirow{4}{*}{$\begin{array}{l}\text { Cotton } \\
(n=33)\end{array}$} & \multirow[t]{2}{*}{ Zinc (n=11) } & I & 3 & 27.27 & 7 & 63.63 & 1 & 9.09 \\
\hline & & & II & 2 & 18.18 & 8 & 72.73 & 1 & 9.09 \\
\hline & & \multirow[t]{2}{*}{ Boron $(n=14)$} & I & 6 & 42.86 & 8 & 57.14 & 0 & 0.00 \\
\hline & & & II & 4 & 28.57 & 10 & 71.43 & 0 & 0.00 \\
\hline \multirow[t]{4}{*}{5.} & \multirow{4}{*}{$\begin{array}{l}\text { Maize } \\
(n=30)\end{array}$} & \multirow[t]{2}{*}{ Zinc $(n=7)$} & I & 5 & 71.43 & 2 & 28.57 & 0 & 0.00 \\
\hline & & & II & 4 & 57.14 & 3 & 42.86 & 1 & 14.29 \\
\hline & & \multirow{2}{*}{$\operatorname{Boron}(n=5)$} & I & 4 & 80.00 & 1 & 20.00 & 0 & 0.00 \\
\hline & & & II & 3 & 60.00 & 2 & 40.00 & 0 & 0.00 \\
\hline
\end{tabular}


Table.4 Comparison of micro nutrient utilization between two successive years

\begin{tabular}{|c|c|c|c|c|c|}
\hline \multirow[t]{2}{*}{$\begin{array}{l}\text { Sl. } \\
\text { No. }\end{array}$} & \multirow[t]{2}{*}{ Crop } & \multirow[t]{2}{*}{$\begin{array}{c}\text { Micro } \\
\text { nutrients }\end{array}$} & \multicolumn{2}{|c|}{$\begin{array}{c}\text { Average quantity in } \\
\text { Kilograms }\end{array}$} & \multirow[t]{2}{*}{ Paired $\mathrm{t}$ - value } \\
\hline & & & $1^{\text {st }}$ year & $2^{\text {nd }}$ year & \\
\hline \multirow[t]{2}{*}{1.} & \multirow[t]{2}{*}{$\begin{array}{l}\text { K-Paddy } \\
(\mathrm{n}=150)\end{array}$} & $\underset{(\mathrm{n}=112)}{\mathrm{Zn}}$ & 12.26 & 15.79 & $1.98 * *$ \\
\hline & & $\begin{array}{c}\mathrm{B} \\
(\mathrm{n}=56)\end{array}$ & 0.65 & 0.85 & $2.04 *$ \\
\hline \multirow[t]{2}{*}{2.} & \multirow[t]{2}{*}{$\begin{array}{l}\text { R-Paddy } \\
(\mathrm{n}=105)\end{array}$} & $\begin{array}{c}\mathrm{Zn} \\
(\mathrm{n}=52)\end{array}$ & 8.34 & 9.82 & $2.11^{*}$ \\
\hline & & $\begin{array}{c}B \\
(n=26)\end{array}$ & 0.32 & 0.56 & $2.23^{*}$ \\
\hline \multirow[t]{2}{*}{3.} & \multirow[t]{2}{*}{$\begin{array}{l}\text { Sugarcane } \\
(\mathrm{n}=35)\end{array}$} & $\begin{array}{c}\mathrm{Zn} \\
(\mathrm{n}=24)\end{array}$ & 13.33 & 17.50 & $2.07 *$ \\
\hline & & $\begin{array}{c}\mathrm{B} \\
(\mathrm{n}=18)\end{array}$ & 0.83 & 0.89 & $2.10^{*}$ \\
\hline \multirow[t]{2}{*}{4.} & \multirow[t]{2}{*}{$\begin{array}{l}\text { Cotton } \\
(\mathrm{n}=33)\end{array}$} & $\underset{(\mathrm{n}=11)}{\mathrm{Zn}}$ & 8.00 & 13.00 & $2.36^{*}$ \\
\hline & & $\begin{array}{c}\mathrm{B} \\
(\mathrm{n}=14)\end{array}$ & 0.86 & 0.96 & $2.15^{*}$ \\
\hline \multirow[t]{2}{*}{5.} & \multirow[t]{2}{*}{$\begin{array}{l}\text { Maize } \\
(\mathrm{n}=30)\end{array}$} & $\begin{array}{c}\mathrm{Zn} \\
(\mathrm{n}=7)\end{array}$ & 7.31 & 8.36 & 1.55 \\
\hline & & $\begin{array}{c}\mathrm{B} \\
(\mathrm{n}=5)\end{array}$ & 0.20 & 0.20 & 0 \\
\hline
\end{tabular}

** - Significant at 1 per cent

* - Significant at 5 per cent

Table.5 Impact of usage of soil health card on yield of crops

\begin{tabular}{|c|c|c|c|c|c|}
\hline $\begin{array}{c}\text { Sl. } \\
\text { No. }\end{array}$ & Crop & Year & \multicolumn{2}{|c|}{ Average quantity in Quintals } & Paired t - \\
value
\end{tabular}

** - Significant at 1 per cent

* - Significant at 5 per cent 
In case of cotton, significant difference in mean yield was not noticed in the first year after utilization of soil health card. While, it was significant at 5 per cent level in second year after utilization of soil health card. Though there was an increase in mean yields of kharif paddy, rabi paddy and maize, it was not to the significant level.

\section{Utilization of macro nutrients by farmers}

Majority of the farmers belonged to recommended utilization category in both paddy and black gram for the successive two years (Table 1). Nutrient losses were more in case of paddy because of its semi aquatic growth habit. As compared to commercial crops- sugarcane, cotton and maize, paddy was less exhaustive and less nutrient responsive in nature. Even with excess application of nutrients, the uptake is optimum as required by the plant. Over utilisation of fertilizers in paddy does not show significant yield increase. Realizing this, farmers are applying recommended dose of fertilizers to reduce the input cost. Thus, the number of farmers following the macro nutrient recommendations in paddy increased from first year to second year. In study area, mostly black gram was grown in paddy fallow field. It is a nitrogen fixing legume that improves soil fertility.

In commercial crops like sugarcane and cotton, noticeable percent of the farmers belonged to over utilization category in successive two years. In sugarcane and cotton, fertilizers were applied in split doses which lead to excess application of fertilizers by the farmers. Farmers have the notion that more the application of chemical fertilizers more will be the yield specially in case of commercial crops. In the expectation of higher yields, over utilization of macronutrients in sugarcane had increased from first year to second year. In case of cotton, over utilization of macro nutrients decreased from first year to second year due to the appearance of toxic symptoms in their fields.

Considerable per cent of the farmers belonged to over utilization category in maize for the past two years. Maize is a highly fertilizer responsive and exhaustive crop. With the expectation of higher yield, farmers applied excess amount of fertilizers. Over utilization of macro nutrients in maize decreased from first year to second year. Farmers might have realized that excess utilisation has no significant influence on yield.

\section{Utilization of micro nutrients by farmers}

Appreciable percentage of the farmers belonged to recommended utilization category of micro nutrients in paddy, sugarcane and cotton crops (Table 3). Farmers came to know about micro nutrient deficiencies in their soil through soil health card. Micro nutrient deficiencies were corrected by adding recommended compounds to the soil. In addition, government also provides subsidy on micronutrients to reduce the burden of high cost. It paved way to majority of the farmers to apply recommended dose of micro nutrients.

Excessive attention of farmers towards macro nutrient application in maize had reduced the attention towards micro nutrient application and its importance. This might be the reason for under utilization of micro nutrients in maize.

The number of farmers following micronutrient application as per recommendation had increased from first year to second year. Farmers became aware of the importance of micronutrients and its contribution to yield. Efforts of soil health 
card scheme's awareness programmes and also increased interaction with extension personnel have contributed a lot in this regard

\section{Impact of soil health card on yield}

The paired ' $t$ ' test reflected positive and significant effect of soil health card on sugarcane and cotton yield (Table 5). Soils in study area are deficient in micronutrients and soil amendments. This scheme gave more emphasis on importance of micronutrients and soil amendments through awareness programmes. Due to the application of micronutrients and soil amendments as per recommendation, their crop productivity was enhanced resulting in better yields.

It can be concluded that application of macro nutrients as per soil health card recommendation was noticed in paddy and black gram. Micro nutrient application as per recommendation was observed in paddy, sugarcane and cotton. Over utilization of macro nutrients was observed in commercial crops like sugarcane and cotton. Farmers perceived that, soil health card have made significant effect on increasing crop yield. There is a still scope to increase crop production and in turn productivity. Mere distribution of soil health card will not serve the purpose of the scheme, sustained efforts are needed by the extension machinery to convince the farmers to use recommended doses for obtaining sustainable yields over a period of time.

\section{Acknowledgement}

I place my gratitude and sincere thanks to Dr.JAGADEESH G. ANGADI, Professor, Department of Agricultural Extension Education, College of Agriculture, Dharwad for his meticulous and infallible guidance with sustained interest, enthusiastic encouragement and critical appraisal throughout the period of this investigation. Besides my advisor, I would like to express my deep sense of gratitude to the members of my advisory committee, Dr. S. L. PATIL, Professor, Department of Agricultural Extension Education, College of Agriculture, Dharwad and Dr. M. P. POTDAR, Professor, Department of Agronomy, College of Agriculture, Dharwad, for their encouragement, insightful comments, and overwhelming support during my course of investigation.

\section{References}

Anonymous, 2012, Compendium on soil health, Dept. Agric. Coop., New Delhi. p. 2-5.

Makadia, J.J., Mistry, H.H., and Kuthe, S.B. 2017.Impact of soil health card on fertilizer consumption and yield of sugarcane and kharif paddy in Gujarat state. Economic affairs., 62(1): 61-66.

www.soilhealth.dac.gov.in

\section{How to cite this article:}

Padmaja, B. and Angadi, J.G. 2018. Utilization of Soil Health Card by Farmers in Nutrient Management. Int.J.Curr.Microbiol.App.Sci. 7(12): 1583-1592.

doi: https://doi.org/10.20546/ijcmas.2018.712.186 